\title{
Kashyapa Rishi of the Mahabharata becomes Dhanvantari Ojha of the Manasamangal Kavya: Transmission and Diffusion of an Ancient Snakebite-Curer's Story
}

\author{
Rahul Bhaumik \\ Department of History, Jadavpur University, Kolkata, India. \\ Email: rahuljoy1981@yahoo.com
}

\begin{abstract}
This paper focuses on the particular Mahabharata story of great snakebite-curer Kashyapa Rishi, whose resemblance we find in the character of Dhanvantari Ojha of the mediaeval Bengali narrative poetry Manasamangal Kavya or Padma Purana. Similarities between these two narratives prove that ancient epical story largely influenced the making of mangal-kavya, though the story of Dhanvantari is not a blind imitation of the epical story. However, a close reading of these stories also indicates towards the very existence of a well-established medical discipline concerning snakebite envenomation and its treatment in ancient and mediaeval India. Thus, by using specific literary evidences this paper actually tries to trace the socio-cultural journey of Indian toxicology.
\end{abstract}

Keywords: Snake, Snakebite-Curer, Takshaka, Kashyapa Rishi, Dhanvantari Ojha, the Mahabharata, the Manasamangal Kavya.

\section{Introduction}

Histories of early India tell us about the fascinating stories of the hard struggle of human beings for a secure and comfortable living in that hazardous mundane world of remote past (for example, see Chakrabarti, 2006; Habib, 2013; Singh, 2009; Thapar, 2002). There is no doubt that, the ancient people of India had to face and also cope with various adverse conditions that afflicted them both physically and mentally. Snakebite envenomation essentially was one of them, an unavoidable health burden, which by destroying tissue and causing massive swelling and internal haemorrhage, or by simply paralysing the body parts, inflicted painful deaths every year on a huge number of human and non-human victims. It is not surprising, therefore, that early Indians began to study various species of snakes, their behaviours, and the symptoms and effects of their bites to safeguard themselves and their cattle (for details, see Slouber, 2017: 1-131). Thus, gradually a specialised discipline called sarpavidya or science of snakes was developed in early India (Bhaduri et al, 2009: 550; Slouber, 2017: 23). From the Vedic period there were some indigenous healers, specialists in sarpavidya, who meticulously engaged themselves with venomous snakes and their venoms. By their prolonged perseverance associated with scientific study, they acquired the ability to recognise several kinds of disorders induced by snake venoms and treat them variously by advising incantations or charms and prescribing numerous herbal medicines, which they themselves discovered (Bhaduri et al, 2009: 550; Slouber, 2017: 19-23). Competence of these physicians in successfully healing the snakebite victims became so essential and popular in the snake-infested country that, in a good number of ancient Indian texts, they were largely thought to possess the qualities of divine healers. It was in this context, that, the occupational title Garudika (poison doctor) was coined in early India (for the term, see Slouber, 2017: 47-48, 69-72). It is an ancient medical term derived from the name of famous bird deity Garuda, the mount of great Hindu god Vishnu and also mortal enemy of 
snakes and poisons, which actually manifest that these snakebite-curers were considered to be god-like in stature.

However, the great Indian epic Mahabharata is probably the first text to directly provide the name and activity of such a divine healer. In the first book of this Sanskrit epic we find the name of Kashyapa Rishi, an ancient sage having knowledge of magical mantras, who possessed the deepest medical knowledge and expertise to heal even a moribund victim bitten by the most pernicious snake of the world. The epical story and myth regarding the capacity of this celebrated ancient physician to cure snakebite patients and bring them back to life, became immensely popular and influenced later writers of various vernacular literature. In this paper, we focus on the remarkable story about the sage Kashyapa and the virulent snake Takshaka of the Mahabharata and also its profound impact on the later creation, more precisely, on the story of Dhanvantari Ojha in the medieval Bengali narrative poetry Manasamangal Kavya. In so doing, we try to show how ancient epical stories and myths metaphorically reflect the very existence of an enriched tradition of snakebite medicine in early India and how the trajectory of this toxicological tradition extended further to leave a deep impression even after thousands of years on the Manasamangal poems of mediaeval Bengal. Thus, this paper actually becomes a prelude to understand how the remote past continuously impinges on the near past and through this process how the history of human activities through ages and their interconnections assume a tangible form.

\section{The Story of Kashyapa and Takshaka in the Mahabharata}

The Mahabharata, usually taken as a composition of Maharshi Shri Krishna Dvaipayana Veda Vyasa, encompasses eighteen books (parvans) of varying proportions, and tells the story of two sets of cousins of Kuru race - the Pandavas and the Kauravas—before, during and after the great war at Kurukshetra or Kuru-land. This great Sanskrit epic of classical India, composed over several centuries, perhaps between circa $400 \mathrm{BCE}$ and $400 \mathrm{CE}$, is truly an encyclopaedic masterpiece (for a discussion on the Mahabharata, see Winternitz, 1977: 311-475). Interestingly, it contains a variety of powerful anecdotes and myths associated with venomous snakes that have captured the imagination of millions of people over the centuries (see Vogel, 1926: 47-92). Moreover, as Michael Slouber rightly points out, the main frame story of the Mahabharata is based on the account of a particular snake related endeavour, which is the snake sacrifice (sarpasatra) of the famous king Janamejaya (Slouber, 2017: 24). Thus, stories connected with snakes are so integral components of this epic that it is absolutely difficult to think about the Mahabharata as something separated from these narratives. Composition of these accounts in this epic, indicates that a close entanglement between human and non-human species happened to exist during the period within which this text was composed and circulated and also shows that early Indians used to apprehend the importance of every animal in nature for living a healthy and wealthy life. This also designates the early Indian environmental thought that the affairs of human life cannot be isolated from that of wildlife and nature. It is against this scenario of realising nature as it is, that the story of sage Kashyapa and snake Takshaka flourished; this interesting story may guide us to understand the history of toxicology in early India.

According to the Adiparvan (The Book of the Beginning), the first book of the epic, Brahma, the divine creator of the universe and various beings in it, bestowed Kashyapa Rishi with the vishahari vidya to counteract the action of snake poison for the good and benefit of humankind (Mahabharata 1/20/16). Empowered with this medical virtue - the power of curing anyone envenomed by snake-this celebrated snakebite-curer always kept him ready to heal the victims of poisonous snakes. The narrative later goes that, king Parikshit, descendant of the Kurus, once went for hunting and wounded a deer which was lost in the forest. Searching for the wild animal into the deep forest, Parikshit came upon a hermit who was under a vow of silence. The king asked the sage if he had seen the deer go by, but did get no reply from him. Because the ascetic did not reply, infuriated Parikshit picked a dead snake with the end of his bow and wrapped it round the hermit's neck. After this act of disrespect, altogether unbecoming of a king, Parikshit returned to his capital Hastinapur (Mahabharata 1/40/10-23). When the hermit's volatile son Sringi heard that his father had been insulted in this way, he became extremely infuriated and cursed that within seven days king Parikshit would be bitten by the divine snake Takshaka and die (Mahabharata I/41/10-14). Knowing about this curse from a messenger, repentant Parikshit made every effort to prevent the fated snakebite death, carefully guarded himself by doctor with healing herbs and brought in 
Brahmins with magic spells from all around (Mahabharata I/42/17-30). On the seventh day renowned physician Kashyapa Rishi heard of the curse, and started for the king to save him with the mantra that used to destroy the lethal effect of venom, hoping to earn considerable wealth and virtue (Mahabharata 1/42/33-34). On his way to the kingdom of Parikshit to save the anathematised king from death by snake poisoning, Kashyapa surprisingly met the serpent king Takshaka who was on his mission to kill the king. Takshaka warned the wise snakebite-curer that he would not be able to heal the king if bitten by the divine snake. But, Kashyapa boldly claimed that he possessed the art of counteracting the most potent venom (vidyabala) of the earth (Mahabharata 1/42/36-41). To prove his words Kashyapa successfully used his medical knowledge and expertise to revive a banyan tree which was reduced to ashes by the virulent effect of Takshaka's venom. The epical narrative goes that Kashyapa ultimately was convinced to turn back and refrain from assisting the king when Takshaka promised to give the snakebite-curer more money than the king might offer for his medical skill and virtue. Kashyapa realised that king Parikshit was destined to die that day in any case. He accepted Takshaka's offer and turned back (Mahabharata I/43/120).

Here is the dialogue between Kashyapa and Takshaka in the Astikaparvan of the first book of the Mahabharta which gives us a glimpse of the above story:

Kashyapa said:

The best of snakes, Takshaka, will to-day burn the chastiser of his enemies, king Parikshit of the Kuru race;

O amiable man, I am going in haste without loss of time, to cure that king of immeasurable prowess, the sole representative of the Kuru race, when he will be bitten by the king of snakes, who is as powerful as Agni.

Takshaka said:

O Brahmana, I am that very Takshaka, who will kill that king of the earth, Stop, you cannot cure one who is bitten by me.

Kashyapa said:

I am possessed with the power of learning. Going there, I am sure I shall cure the king bitten by you.

Takshaka said:

O Kashyapa, if you are able to cure any creature bitten by me, then revive this tree bitten by me.

O best of Brahmanas, I burn this banian tree in your sight. Try your best; and show me your skill in Mantras of which you have just spoken.

Kashyapa said:

O snake, if you are so minded, bite (the tree then). I shall revive it, though bitten by you.

Sauti said:

The king of the snakes, thus addressed by the illustrious Kashyapa, bit that banian tree.

The tree, bitten by the illustrious snake and having embibed his poison, blazed up all around.

Having thus burnt the tree, the snake spoke again to Kashyapa ' $O$ best of Brahmanas, try your best and let this lord of the forest (the banian tree) be revived.'

The tree was reduced to ashes by the poison of the king of snakes. But taking up the ashes, Kashyapa spoke these words.

'O king of snakes, behold my power of learning in this lord of the forest. $\mathrm{O}$ snake, I shall revive it in your very presence.'

And then that best of Brahmanas, the illustrious and learned Kashyapa, revived by his learning the tree which was reduced to a heap of ashes. 
He first created the sprout, he then created two leaves in it. He then made the stem, then the branches and then the full-grown tree with leaves and all.

Seeing that the tree was really revived by the illustrious Kashyapa, Takshaka said, 'O Brahmana, it is not (at all) wonderful.

That you should destroy my poison or the poison of others like me. $\mathrm{O}$ king of Brahmanas, $\mathrm{O}$ Rishi, wishing to gain what wealth, are you bent on going there?

I shall give you the wealth you hope to get from the best of kings, however difficult may it be to get it.

O Brahmana, your success is doubtful, for that king is affected with a Brahmana's curse and the period of his life is also shortened.

Your blazing fame, that has overspread the three worlds, will (then) disappear the sun deprived of his splendour.

Kashyapa said:

I go there for wealth. Give it to me, O snake, so that I may go back receiving it from you.

Takshaka said:

O best of Brahmanas, I shall give you wealth more than you hope to get from the king. Therefore do not go. (Dutt, 2013: 129-130)

After the great snakebite-curer Kashyapa's departure, Takshaka went towards Hastinapur in order to carry out the curse. On his way, he heard that the king was being carefully protected with poisonneutralising mantras and antidotes. Therefore, he assumed the form of an ugly insect, and burrowed into a fruit, which was being taken to the king Parikshit's palace by a group of ascetics (actually by a group of snakes in disguise). When the king took the fruit offered by the so called sages, Takshaka assumed his original form, bit and killed Parikshit as he was destined to do (Mahabharata I/43/20-36). It was this fateful incident which later instigated king Janamejaya, son of Parikshit, to retaliate for his bereavement due to the loss of his father and perform sarpasatra (snake sacrifice) where snakes were thrown as offerings to fire to altogether annihilate the snake race (Mahabharata, l/52/1-10). Although, this incendiary reaction of king Janamejaya for his father's untimely death caused near extinction of the whole serpent race, the idea of collectively killing snakes was not encouraged thoroughly in the epic and this particular incident actually reflects only the extreme shock and bereavement of a son. The story of sarpasatra, therefore, inevitably ends with a conclusion glorifying the notion of forgiveness as king Janamejaya, persuaded by the wise word of a learned sage named Astika, son of Jaratkaru and the snake-goddess Manasa, stopped the sacrifice and ended all the enmity towards the snakes (Mahabharata I/55-58).

However, commenting on the above quoted verses of the Mahabharata, Priya Vrat Sharma pertinently hinted that the discourse between Takshaka and Kashyapa is evidently a proof of the latter's expertise in the science of toxicology (Sharma, 1992: 91). A close reading of this discourse certainly reveals that, some skilled snakebite-curers existed in that period in early India when the Mahabharata gradually was being composed. These ancient physicians, undoubtedly, possessed considerable knowledge of toxicology by which they regularly and successfully used to heal patients lethally bitten by venomous snakes or other poisonous animals. The above verses also reflect that the outstanding healing capability of these medical-men, the professional nature of their practices and their commitment to the assigned job, often provided them with the opportunity to earn ample money. The occupation or the profession of Garudika in early India was therefore neither casual nor unprofitable. What is important to note here is that, the Mahabharata is not an isolated case, several other ancient pieces like the Vedas, the Ramayana, the Puranas, the Jatakas and all the early Aurvedic texts clearly provide evidence that such healers did exist in the form of sages or seers in early India (for details, see Slouber, 2017: 1-131). Presence of such a huge number of sages involving in the healing of snakebite victims all over the country, actually indicates early Indians' deep concern about the disease of snake poisoning and also that the science of poison became an well-established discipline and a significant part of therapeutic activities in this country. This toxicological tradition continued unabated in later ages and a large number of later vernacular literature like Manasamangal Kavya were vastly influenced by this tradition. 


\section{The Story of Dhanvantari Ojha in the Manasamangal Kavya}

Much attention is not required to realise that the above epical anecdote of Kashyapa Rishi considerably inspired the preliminary making of the account of Dhanvantari Ojha alias Sankha Dhanvantari or Sankar Gadari of the Manasamangal Kavya or the Padma Purana. The Manasamangal, which glorifies snakegoddess Manasa or Padma's victory over those who initially refused to worship her, is a vernacular Bengali narrative poetry, composed, as far as we know from the surviving texts, in between the thirteenth and the eighteenth centuries (for a detail discussion, see Bhattacharyya, 1970: 237-415; Dimock, 1962; Maity, 1966; Sen, 2007a: 155-203; Sen, 2007b: 222-253). This mangal-kavya is actually a narrative song (mangal-gan) generally performed by the less-literate ordinary village singers (see Bhattacharjee, 2006; Bhattacharya, 2006: 105-106; Chatterji, 2014) and therefore, offers a detailed image of the then lowerclass social world, which is reflected in the activities of its main characters, and as a matter of fact, perfectly furnishes a long specimen of oral and folk culture of that time. Asutosh Bhattacharyya remarks that, the tale of Manasa gained the widest popularity of all the classes of folk-literature in mediaeval Bengal, Assam and Bihar. Several poets composed verses with the same theme of the tale which was carried down the generations for centuries (Bhattacharyya, 1965: 10). The basic plot of this poetry is, however, quite uncomplicated and directly related to the purpose of "religious proselytising" (Curley, 2008: 10). According to the storyline, a true devotee of the god Siva, Chand Saudagar, was totally unwilling to adore the snake-goddess Manasa and insulted her. Manasa sent a snake to bite Lakhindara, youngest son of Chand, who died due to the envenomation on his wedding night. After getting a promise from Lakhindara's wife Behula that Chand would venerate Manasa, the goddess brought Lakhindara back to life by her supernatural power over snake and its venom. In this regard, scholars argue that:

[...] like Manasa herself, her tale is a composite thing, told, retold, the theme of destructionregeneration drawing to itself different folk tales and myths, becoming episodes in a single story of the triumph of the goddess Manasa (Dimock and Ramanujan, 1964: 322).

According to Dinesh Chandra Sen, mangal-kavyas are intimately linked with the epic and puranic stories in Sanskrit literature and the Bengali Hindu narrative poems devoted to the deities like Manasa (Sen, 1954: 157-161). So the tradition of snake-story-telling belonged simultaneously to the epic-puranic literature and Bengali folklore. It is in this context, the Mahabharata story of Kashyapa Rishi has easily been incorporated into the Manasa saga as the narrative of Dhanvantari Ojha.

However, it is pertinent to note here that, as a physician of gods and goddesses, Dhanvantari first appeared when the Hindu gods and the demons joined hands to churn the Ocean of Milk to extract amrita or elixir of immortality. According to Hindu myth, during the samudra manthan, Dhanvantari emerged from the Ocean of Milk with the pot of amrita along with fourteen ratnas or treasure jewels, followed by the goddess Shri Lakshmi seated on a lotus in full bloom (Dallapiccola, 2010: 27-28). Commonly worshipped as the god of medicine, Dhanvantari is regarded as the original exponent of Ayurvedic medicine. Interestingly, in the Manasamangal Kavya or the Padma Purana, the character of Dhanvantari Ojha, who was also born from the churning of the ocean, largely resembles the character of the sage Kashyapa. In almost every version of the Manasamangal, like Kashyapa Rishi of the Mahabharata, Dhanvantari Ojha is known to possess the supreme knowledge of poison or mahagyan by which he could even revive victim died due to snakebite envenomation. In the Padmapurana of Vijayagupta and the Manasa-Vijaya of Vipradasa, Sankar Gadari did exactly everything that was done by snakebite-curer Kashyapa in front of Takshaka in the first book of the Mahabharata (Dasgupta, 2009: 167; Sen, 1953: 46-49). The same epical story of Kashyapa and Takshaka is also repeated in the Vishnu Pala's Manasa Mangala, where Kashyapa Rishi became Kupila Muni (Sen, 2002: 28-29).

The anecdote of Dhanvantari Ojha, however, is not a blind imitation of the epical story. Rather, the account here is much prolonged than that of the epical one and intimately related to the tradition of snakebite-medicine practised by Ojha, Gunin, Kaviraj, Vaidya and Bede. The brief narrative, which is beautifully translated by Edward C. Dimock and A. K. Ramanujan, put as follows:

After razing his estates, Manasā appeared to Cāndo in a dream, commanding him to worship her. But in the morning Cāndo summoned some of his friends and consulted them. They advised him to employ the great ojhā Dhanvantari to protect himself from Manasā. Cāndo did so, and on his arrival in Campakanagara, Dhanvantari by his magic restored all of Cāndo's estates. Manasā 
again consulted Neto, who advised her first to destroy Dhanvantari, thereby making Cāndo easier game (Dimock and Ramanujan, 1964: 309-310).

Neto, in a bid to guide Manasa, also advised the goddess to befriend Dhanvantari's wife Kamala, and tactfully know from her the secret of killing the celebrated snakebite-curer. Dressing as a Brahman woman, Manasa quickly met Kamala, pretended to be worried for the well-being of her husband and asked her what would happen if Dhanvantari was to die. The later story goes as follows:

Kamalā was tormented by the idea after Manasā had left and was weeping when Dhanvantari came in. In response to her question, Dhanvantari replied that he could not die unless the seven marks of Brahmā on his head were obliterated, and that this could be done only if the udaykāl snake were to enter his nostril. Manasā, perched on the wall in the form of a white fly, heard all this. She went immediately to Śiva, in whose possession the udaykāl snake was, and persuaded him to give the snake to her. The snake entered Dhanvantari's nostril and struck.

Awakening and knowing that he was dying, Dhanvantari summoned his two chief pupils, Dhanā and Manā, and told them that the only antidote for the poison was in the saalya tree. The pupils went at once to the mountainside and found the tree; but as they were coming down the path with it, Manasā appeared before them in the disguise of an old Brahman woman, weeping. When they asked her why she cried, she replied: ' $O$ children, what is the use of medicine? Your guru just gave up his life because of the enmity of Manasā. The smoke you see is that of your guru being burned. Listen-you can hear the sounds of wailing in the city.' So the pupils dropped the tree and ran to the side of Dhanvantari, who was alive. His last request to his pupils was that they cut his body into four pieces and bury them in the four directions.

The boys then began to cut the body into pieces, but before they had had time to finish the task, Manasā appeared again in the form of an old Brahman woman. She rebuked the boys, telling them that they should have more respect for their guru's body. Ashamed, they buried the body whole (Dimock and Ramanujan, 1964: 310-311).

Thus, for his marvellous power of curing the disease of snake poisoning, Sankha Dhanvantari became the chief protector of Chand Saudagar and his family and also the main enemy of snake-goddess Manasa who wanted to teach Shiva's greatest devotee, Chand, a lesson by killing his beloved sons. The striking fact here is that, the profession associated with snakebite-medicine was so popular and prestigious in mediaeval Bengal that a large section of Manasamangal had to deal with the tale of Dhanvantari Ojha. The narrative definitely provides us with a good idea of the folk and also glimpses of prevalent tantric medical procedure of healing venomous snakebite in the mediaeval society. Furthermore, the friendly relationship between Chand Saudagar and Sankha Dhanvantari is an indication of an amicable socio-cultural environment which surely inspired the indigenous medical system to flourish.

\section{Conclusion}

By focusing on the Mahabharata story of eminent snakebite-curer Kashyapa and its deep influence over the creation of mediaeval Bengali character Dhanvantari Ojha, this paper have tried to demonstrate that the traditional practice of snakebite-medicine gradually developed through the ages, its practitioners enjoyed great respect and popularity in those days and the anecdotes of snakebites inspired writers of genre generation after generation. Our engagement with the stories have also showed that, although, the Sanskrit Mahabharata considerably attracted the attention of poets of the Manasamangal Kavya and some basic elements of the Manasa saga originated from the epic, in many ways these vernacular writers departed from and went beyond the Sanskrit narrative and created their own masterpieces essentially to conform to the local socio-cultural realities of that time. Besides this, our study have also pointed out to the fact that, popular stories concerning snake and snakebite, which belong to a genre literature, may often prove useful to the historians, if handled with utmost care, insight and ingenuity, especially for those who wish to write a sizeable history of Indian toxicology. 


\section{Acknowledgement}

Part of this article was read as a paper at the International Seminar 2017 on "Pre-Modern Bengali Literature and Culture", held at the Department of Bengali, Rabindra Bharati University, Kolkata, India. I would like to thank the organisers of the seminar.

\section{References}

Bhaduri, J. L. et al. (2009). Zoology. In D. M. Bose et al. (Eds.), A Concise History of Science in India. Hyderabad: Universities Press. 534-582.

Bhattacharjee, Kishore. (2006). Constructing Community, Gender and Kinship through Epic Singing. Indian Folklore Research Journal. Vol. 3. No. 6. 1-12.

Bhattacharya, Asutosh, (2006). Folklore of Bengal. New Delhi: National Book Trust.

Bhattacharyya, Asutosh, (1965). The Serpent as a Folk-Deity in Bengal. Asian Folklore Studies. Vol. 24. No. 1. 1-10.

Bhattacharyya, Asutosh, (1970). Bangla Mangal Kavyer Itihas. Kolikata: A. Mukherjee and Co.

Chakrabarti, Dilip K. (2006). The Oxford Companion to Indian Archaeology: The Archaeological Foundations of Ancient India, Stone Age to AD 13th Century. Delhi: Oxford University Press.

Chatterji, Roma. (2014). Folk Theatre on the Modern Stage: Manasa - Death Dealer / Life Giver. Indian Anthropologist. Vol. 44. No. 2. 1-18.

Curley, David L. (2008). Poetry and History: Bengali Mangal-kabya and Social Change in Precolonial Bengal. New Delhi: Chronicle Books.

Dallapiccola, A. L. (2010). Hindu Myths. New Delhi: Orient BlackSwan.

Dasgupta, Jayanta Kumar. (Ed.). (2009). Kabi Vijaygupter Padmapurana. Kolkata: Kolikata.

Dimock, Edward C. (1962). The Goddess of Snakes in Medieval Bengali Literature. History of Religions. Vol. 1. No. 2. 307-321.

Dimock, Edward C. and Ramanujan, A. K. (1964). The Goddess of Snakes in Medieval Bengali Literature: Part II. History of Religions. Vol. 3. No. 2. 300-322.

Dutt, M. N. (Trans.). (2013). Mahabharata: Sanskrit Text and English Translation. Vol. I. Delhi: Parimal Publications. Habib, Irfan. (2015). Man and Environment: The Ecological History of India. New Delhi: Tulika Books.

Maity, Pradyot Kumar. (1966). Historical Studies in the Cult of the Goddess Manasa: A Socio-Cultural Study. Calcutta: Punthi Pustak.

Sen, Dinesh Chandra. (1954). History of Bengali Literature. Calcutta: Calcutta University.

Sen, Sukumar. (Ed.). (1953). Vipradasa's Manasa-Vijaya. Calcutta: The Asiatic Society.

Sen, Sukumar. (Ed.). (2002). Visnu Pala's Manasa Mangala. Kolkata: The Asiatic Society.

Sen, Sukumar. (2007a). Bangla Sahityer Itihas. Vol I. Kolkata: Ananda Publishers.

Sen, Sukumar. (2007b). Bangla Sahityer Itihas. Vol II. Kolkata: Ananda Publishers.

Sharma, Priya Vrat. (1992). Medical Data in Epics and Puranas. In Priya Vrat Sharma. (Ed.), History of Medicine in India: From Antiquity to 1000 A.D. New Delhi: Indian National Science Academy. 87-116.

Singh, Upinder. (2009). A History of Ancient and Early Medieval India: From the Stone Age to the 12th Century. Delhi: Pearson Longman.

Slouber, Michael. (2017). Early Tantric Medicine: Snakebite, Mantras, and Healing in the Garuda Tantras. New York: Oxford University Press.

Thapar, Romila. (2002). The Penguin History of Early India: From the Origins to AD 1300. New Delhi: Penguin.

Winternitz, Maurice. (1977). A History of Indian Literature. Vol. I. New Delhi: Oriental Books Reprint Corporation.

Vogel, J. P. (1926). Indian Serpent-Lore or the Nagas in Hindu Legend and Art. London: Arthur Probsthain.

Rahul Bhaumik received his doctoral degree in 2016 from the Department of History, Jadavpur University, Kolkata, India. His articles have been published in the History Studies: International Journal of History, the Indian Journal of History of Science and the Rupkatha Journal on Interdisciplinary Studies in Humanities. 
17 | Bhatter College Journal of Multidisciplinary Studies, Vol. VII, No.2, 2017, Section I 